\title{
Influence of Crack on Welded Joint Characteristics in Different Types Of Loads
}

\author{
Zijah Burzicic ${ }^{1)}$ \\ Meri Burzicic \\ Vencislav Grabulov ${ }^{3)}$ \\ Srđa Perkovic ${ }^{1)}$
}

\begin{abstract}
The application of high strength steels in design of heavy duty welded structures requires data about properties in different loading conditions. Thanks to high yield stress the wall thickness can be reduced compared to mild structural steels, and accordingly welded joint cross-sections, welding consumables consumption and time for welded joints manufacturing will be minimized. This is of importance for pressurized equipment, but also for other industrial branches (cranes, excavator). Complete characterization of welded joint has to include data for parent metal, but also the properties for weld metal and the heat-affected-zone (HAZ) are necessary, at least in order to compare them with parent metal properties. This is of special importance because of heterogeneity structure in HAZ.
\end{abstract}

Key words: microalloyed steel, welded joint, quality of welded joint, crack, fatigue crack, crack growth, impact testing, fatigue, fracture mechanics.

\section{Introduction}

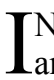
N selecting a material for a particular application, the ease and cost of welding must be considered and the material selected should be that which gives a welded vessel of the adequate properties for the minimum cost. The requirement for cost reduction in pressure vessel manufacturing can be fulfilled by application of steels of increased strength microalloyed steel. Benefit in strength increase can be expressed in reduced pressure vessel wall thickness, followed by significant reduction in welded joint cross-sections, welding consumables and time necessary to produce the welded joints. Benefits which can be obtained by increased strength must be additionally confirmed by sufficient resistance to brittle fracture, e.g. by the resistance to cracks and stress concentration. For that reason data about impact $\mathrm{V}$ notch toughness and about crack behavior in impact and in stable crack growth condition are required before final decision for the selection of high strength steel for manufacturing highly loaded welded structures [1].

Design against brittle fracture should normally be based on fracture initiation, although in certain highly critical components a propagation criterion may be justifiable to give an extra margin of safety. The chance of brittle fracture failure will almost certainly not depend upon the properties of the parent material but on those of the weld metal and HAZ, since in most cases these regions are less tough than the parent material. It is strongly recommended that general yielding or linear elastic fracture mechanics tests are carried out, as appropriate, on welded joints and that the minimum toughness is specified on the basis of the largest defect which could remain undetected in the structure. The fracture mechanics results enable a relationship between stress, defect size, material thickness and toughness to be established [2].

The great majority of service failures involve the initiation of cracking at defects situated in regions of stress concentration. Since in welded structures defects are almost always involved, it is necessary not only to design against overload but also to avoid the possibility of low stress failure by brittle fracture and fatigue. It is important to avoid cracking problems but it would be unrealistic to imagine that, by taking the utmost care during welding, all cracks and defects at welds could be eliminated. However, by maintaining an adequate degree of control by non-destructive testing, it should be possible to ensure that defects exceeding some maximum size will be absent.

Cracks, considered as most dangerous defects in welded joints, are not allowed by welding standards. Although not allowed by the standards, cracks attract the attention of designers and welded constructions users, since after some period of service they are frequently detected during regular in-service inspection of welded joints. It is of interest to know how crack will behave in different welded joint constituent, e.g. in parent metal, weld metal and the heat-affected-zone (HAZ) under different loading conditions, and to assess the degradation degree of parent metal crack resistance induced by welding [2].

Crack resistance can be evaluated by different fracture mechanics parameters. Three of them are in general use:

1) Military Technical Institute (VTI), Ratka Resanovića 1, 11132 Belgrade, SERBIA

2) IC Faculty of Mechanical Engineering, Kraljice Marije 16, 11020 Belgrade, SERBIA

3) IMS Institute, Bul. Živojina Mišića 38, 11000 Belgrade, SERBIA

Correspondence to: Zijah Burzić; e-mail: zijah.burzic@vti.vs.rs 
stress intensity factor $K_{I}$, crack opening displacement (COD) $\delta$ and $J$ integral. It is to notice that their critical values: plane strain fracture toughness $K_{I c}$, critical COD and $J_{I c}$, measure of fracture toughness, can be used as material properties of homogeneous material. The standards for their determination by testing are well defined, applying quasi-static loading. The application of these standards to welded joint is difficult due to its microstructural heterogeneity. In addition to quasi-static loading, applied for tensile and fracture mechanics testing, crack resistance for other types of loading is also significant for designers and welded constructions users, since cracks can be experienced in service. When crack resistance is considered, much more data can be obtained by instrumented impact test, in which it is possible to separate crack initiation and crack propagation energies, than in standard Charpy impact test, in which only total fracture energy is recorded [3].

Complete description of material crack resistance includes data obtained in the following test [4-6]:

- Determination of convenient fracture mechanics parameter ( $K_{I}, \mathrm{COD}-\delta$ or $J$ integral), and, when possible, its critical value. The same testing type comprises the determination of crack resistance curve, the relation between fracture mechanics parameter (e.g. $J$ integral) and crack extension, $\Delta a$.

- Energy for crack initiation and for crack propagation in impact test, applying $V$ notched, but also precracked specimens. Precracked specimen impact testing enables to determine dynamic crack resistance curve.

- Relationship between stress intensity factor range, $\Delta \mathrm{K}$, and crack growth rate, da/dN.

However, when welded joints are considered many problems in testing and results evaluation are connected with their microstructural heterogeneity. These are the reasons it is not possible, like in case of parent metal, to determine properly the crack resistance parameter for welded joint, since the critical microstructural region is not properly defined. Additional problem is connected with parent metal strength. In case of high strength steel, crack resistance in welded joint can be reduced compared to parent metal. On account of that, it is important to determine all the aspects of crack resistance and possible reduction of weld metal properties compared to high strength steel.

Described situation explains the need for crack resistance data of high strength steel welded joint in different loading conditions. The paper presents applied testing techniques and obtained results.

\section{Preparation of samples}

The experiments have been performed with high strength steel of nominal yield strength class $700 \mathrm{MPa}$ and its welded joints. This steel is designed for pressure vessels manufacturing and in shipbuilding, e.g. for submarines. The chemical composition and mechanical properties are shown in Tables 1 and 2, respectively $[5,6]$.

Table 1. Chemical composition of the tested material [5]

\begin{tabular}{|c|c|c|c|c|c|c|c|c|c|}
\hline $\mathrm{C}$ & $\mathrm{Si}$ & $\mathrm{Mn}$ & $\mathrm{P}$ & $\mathrm{S}$ & $\mathrm{Cr}$ & $\mathrm{Ni}$ & $\mathrm{Mo}$ & $\mathrm{V}$ & $\mathrm{Al}$ \\
\hline \hline 0.1 & 0.2 & 0.23 & 0.009 & 0.018 & 1.24 & 3.1 & 0.29 & 0.05 & 0.08 \\
\hline
\end{tabular}

Table 2. Mechanical properties of the tested material [5]

\begin{tabular}{|c|c|c|c|c|c||}
\hline Yield stress & Tensile strength & Elongation & \multicolumn{3}{|c||}{ Impact energy, $J$} \\
\hline \hline$R_{p 0,2}, \mathrm{MPa}$ & $R_{m}, \mathrm{MPa}$ & $A, \%$ & $+20^{\circ} \mathrm{C}$ & $-60^{\circ} \mathrm{C}$ & $-100^{\circ} \mathrm{C}$ \\
\hline$<730$ & $<800$ & $<18$ & $<150$ & $<85$ & $<65$ \\
\hline
\end{tabular}

Samples for investigation have been prepared by manual arc welding (MMAW). Two plates of high strength steel, 18 $\mathrm{mm}$ thick, have been prepared for asymmetric $2 / 3 \mathrm{X}$ welded joint by edge machining. The chemical composition and mechanical properties of applied electrode Tenacito - 80 are shown in Tables 3 and 4, respectively. Welding is performed with $2 \mathrm{~mm}$ gap, in six passes $[5,6]$.

Table 3. Chemical composition of all weld metal, $\%$

\begin{tabular}{|c|c|c|c|c|c|c|}
\hline Electrode & $\mathrm{C}$ & $\mathrm{Mn}$ & $\mathrm{Si}$ & $\mathrm{Cr}$ & $\mathrm{Ni}$ & $\mathrm{Mo}$ \\
\hline \hline Tenacito- 80 & 0.06 & 1.65 & 0.3 & 0.55 & 2.0 & 0.35 \\
\hline
\end{tabular}

Table 4. Mechanical properties of all weld metal

\begin{tabular}{||c|c|c|c|c|c|c|}
\hline \multirow{2}{*}{ Electrode } & $\begin{array}{c}\text { Yield } \\
\text { stress }\end{array}$ & $\begin{array}{c}\text { Tensile } \\
\text { strength }\end{array}$ & Elongation & \multicolumn{2}{|c|}{ Impact energy, $J$} \\
\cline { 2 - 7 } & $\begin{array}{c}R p_{0,2}, \\
\mathrm{MPa}\end{array}$ & $R m, \mathrm{MPa}$ & $\mathrm{A}, \%$ & $+20^{\circ} \mathrm{C}$ & $-40^{\circ} \mathrm{C}$ & $-60^{\circ} \mathrm{C}$ \\
\hline Tenacito-80 & $<710$ & $<770$ & $<18$ & $<50$ & $<35$ \\
\hline
\end{tabular}

\section{Impact testing of Charpy $V$ specimens and precracked specimens}

Impact testing is performed at the room temperature, according to EN ISO 9016:2013 "Destructive tests on welds in metallic materials - Impact tests - Test specimen location, notch orientation and examination" [7], with Charpy specimens $V$ notched in parent metal (BM), weld metal (WM) and HAZ, (Fig.1), on the instrumented Charpy pendulum.
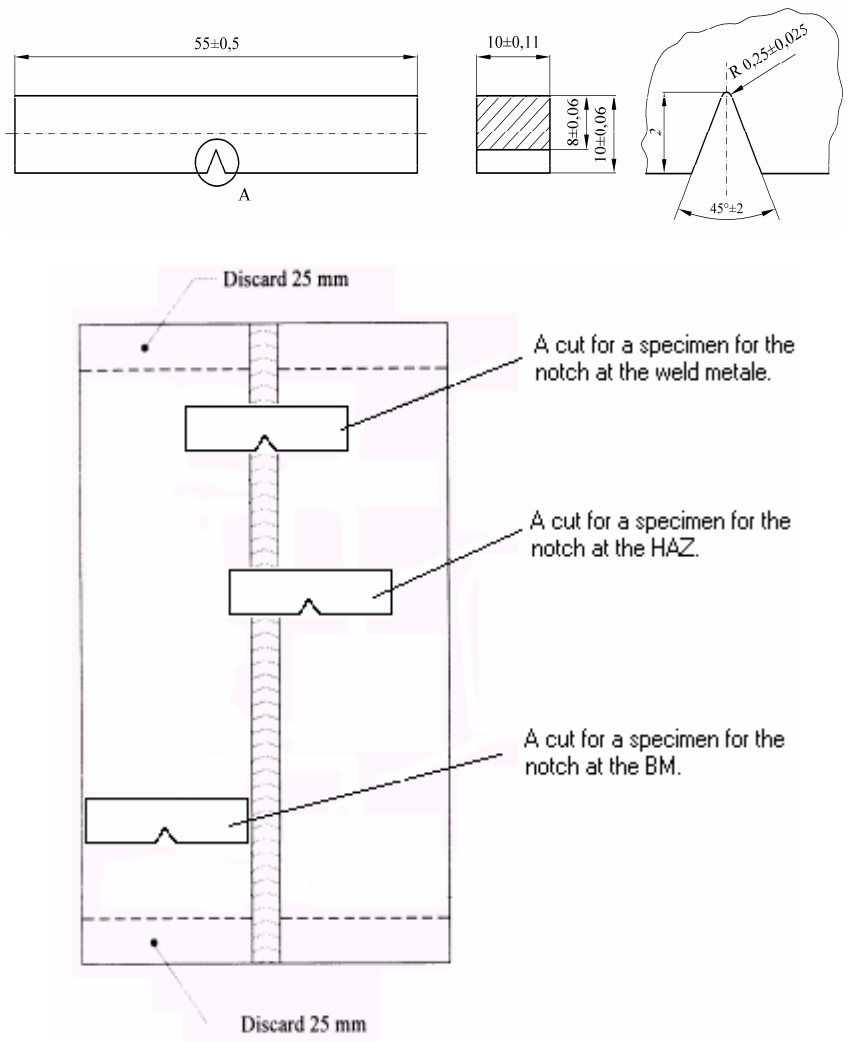

Figure 1. Charpy V specimen and V notch location

Two typical relationships, force vs. time, and energy vs. time, obtained by instrumented impact testing [8], are presented in Fig.2 - 4 for parent metal specimen BM-1, for weld metal specimen WM-1, and for specimen HAZ-1. Obtained results for total impact energy, for crack initiation and propagation, together with deflection values, are summarized in Table 5. 


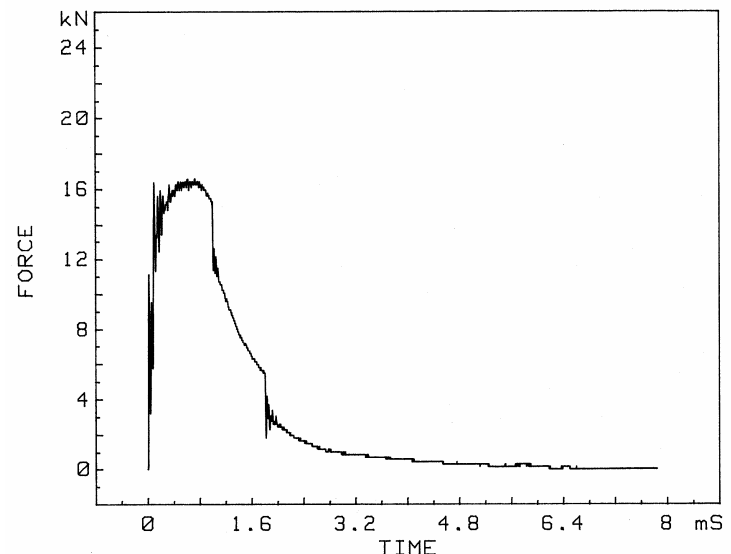

a)

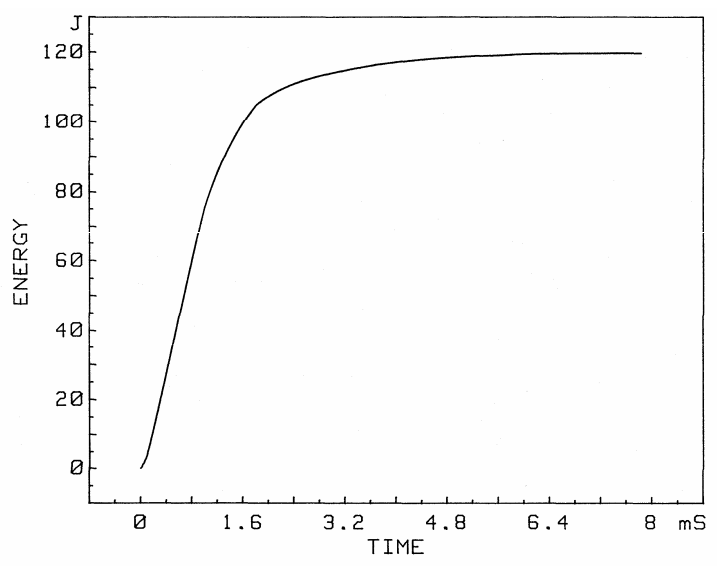

b)

Figure 2. Force vs. time (a), and energy vs. time (b) for specimen BM-1

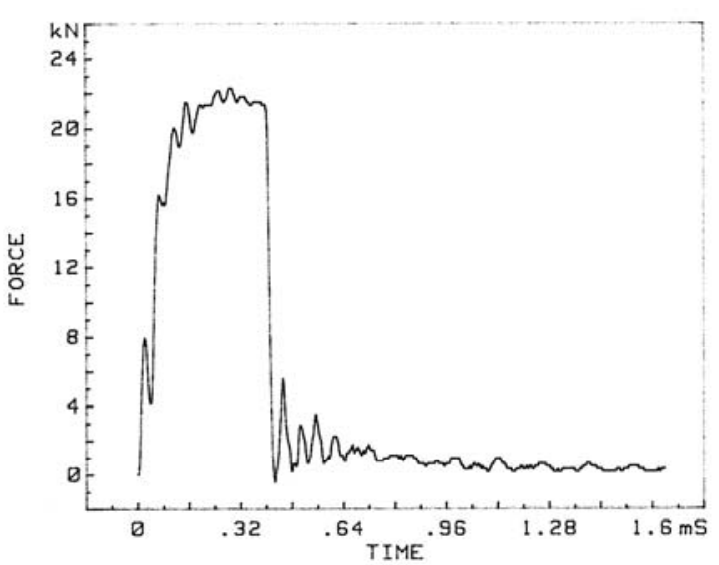

a)

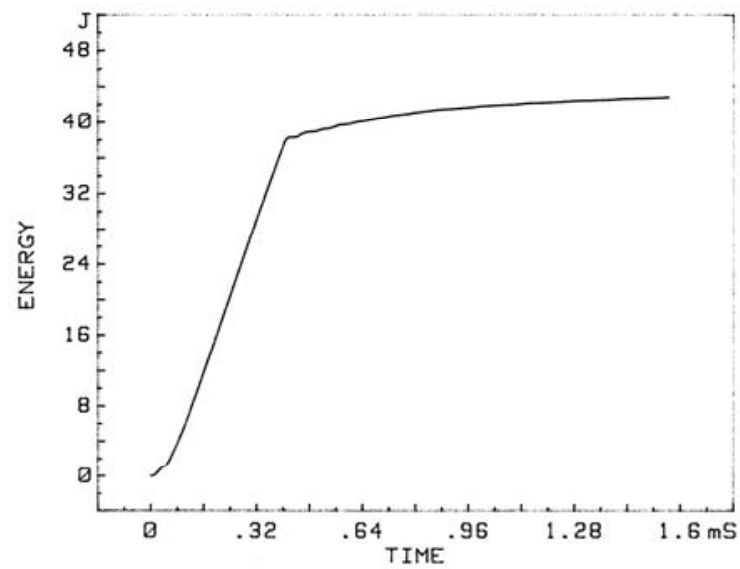

b)

Figure 3. Force vs. time (a), and energy vs. time (b) for specimen WM-1

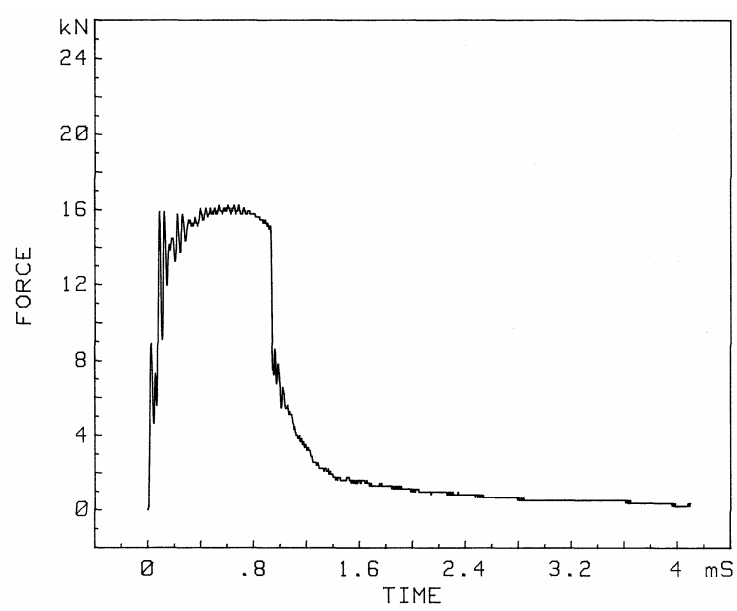

a)

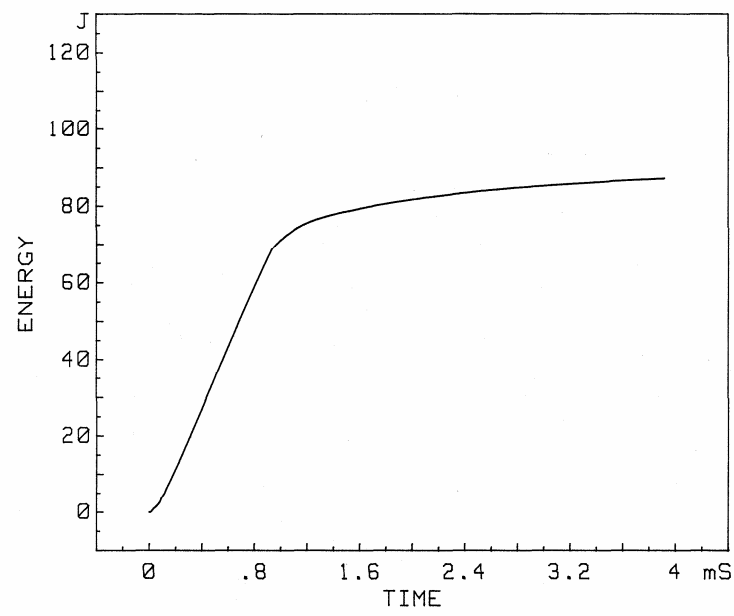

b)

Figure 4. Force vs. time (a), and energy vs. time (b) for specimen HAZ-1

Table 5. Instrumented impact testing results of Charpy $\mathrm{V}$ welded joint specimens

\begin{tabular}{|c|c|c|c||}
\hline Specimen No. & $\begin{array}{c}\text { Total impact } \\
\text { energy, } E_{u}, J\end{array}$ & $\begin{array}{c}\text { Crack initiation } \\
\text { energy, } E_{\text {in }}, J\end{array}$ & $\begin{array}{c}\text { Crack propagation } \\
\text { energy, } E_{p r}, J\end{array}$ \\
\hline \hline BM-1 & 115 & 44 & 71 \\
\hline BM-2 & 106 & 41 & 65 \\
\hline BM-3 & 104 & 42 & 64 \\
\hline WM-1 & 42 & 22 & 20 \\
\hline WM-2 & 53 & 23 & 30 \\
\hline WM-3 & 51 & 22 & 29 \\
\hline HAZ-1 & 82 & 40 & 42 \\
\hline HAZ-2 & 89 & 43 & 45 \\
\hline HAZ-3 & 84 & 41 & 43 \\
\hline
\end{tabular}

Specimens precracked in BM, WM and HAZ have also been tested. Typical relationships, force vs. time, and energy vs. time for specimens with different crack length are presented in Fig.5 for specimen BM-5, Fig.6 for specimen WM-5, and Fig. 7 for specimen and HAZ-5. The difference in crack length of the specimens is a consequence of fatigue precracking procedure applied to different microstructures of materials in BM, WM and $\mathrm{HAZ}$, which responded in a different way. An average value of fatigue precrack length, measured after fracture, in 5 equidistant positions, represents average crack length a. 


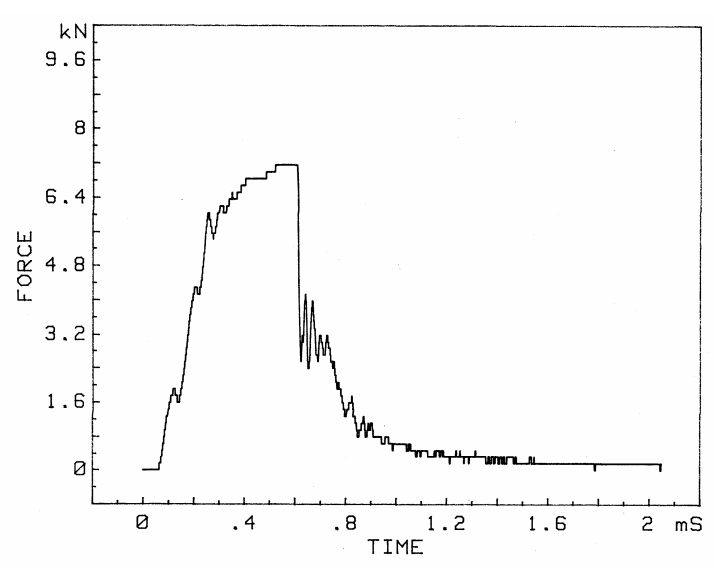

a)

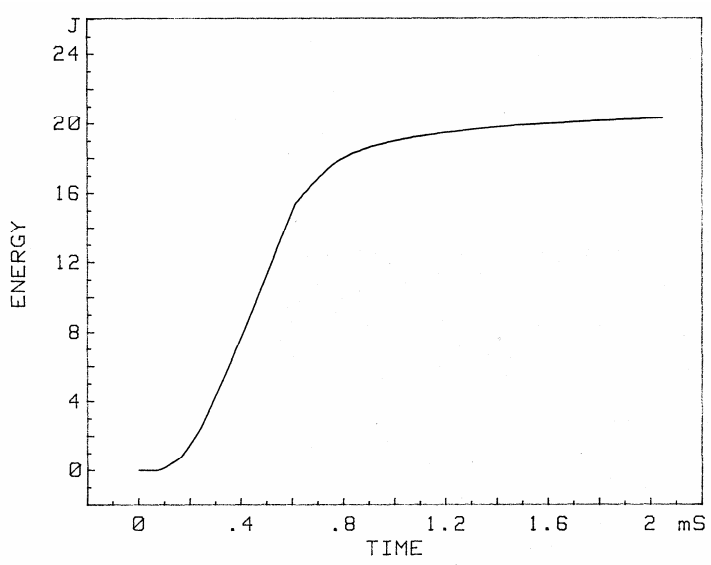

b)

Figure 5. Relationships force vs. time (a), and energy vs. time (b) for specimen precracked in BM (BM-5), crack length $\mathrm{a}=5.03 \mathrm{~mm}$

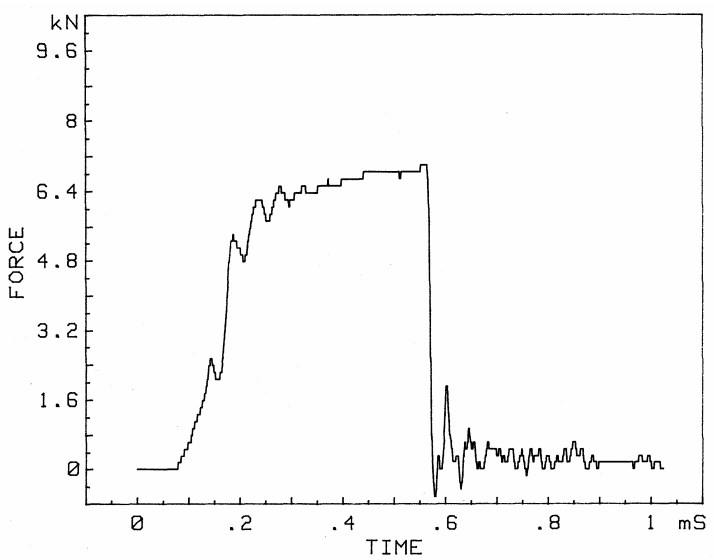

a)

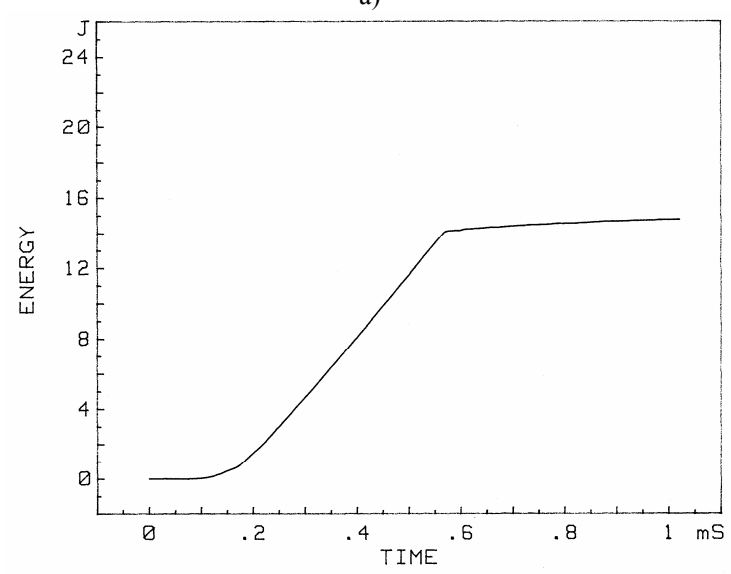

b)

Figure 6. Relationships force vs. time (a), and energy vs. time (b) for specimen precracked in WM (WM-5), a = 5,26 mm

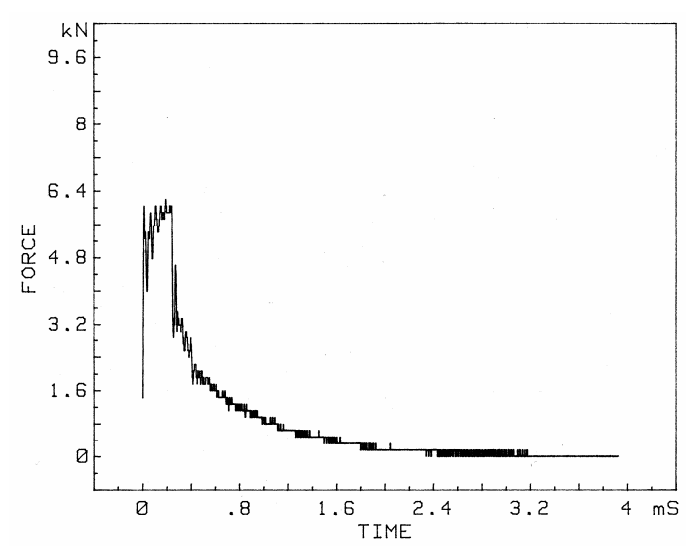

a)

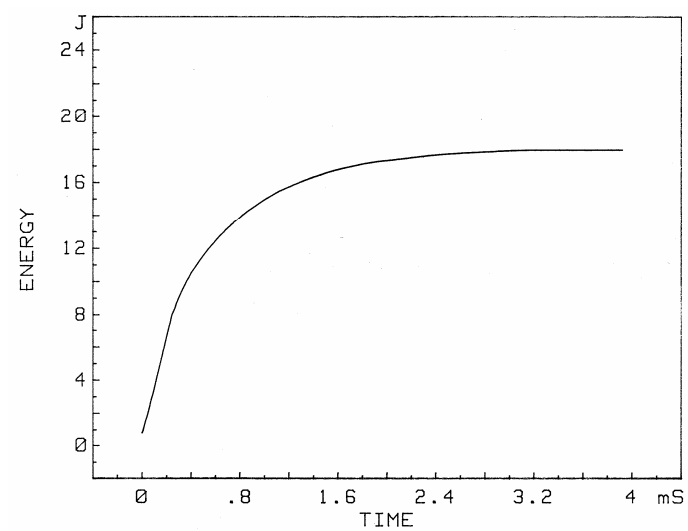

b)

Figure 7. Relationships force vs. time (a), and energy vs. time (b) for specimen precracked in HAZ (HAZ-5), $\mathrm{a}=4,52 \mathrm{~mm}$

Average crack length and corresponding absorbed impact energy $\mathrm{KV}$, present a pair of values for KV vs. a plot, which initiates at notch depth $(2 \mathrm{~mm})$ and follows parabolic law, as presented in Figures 8 - 10 for BM, WM and HAZ.

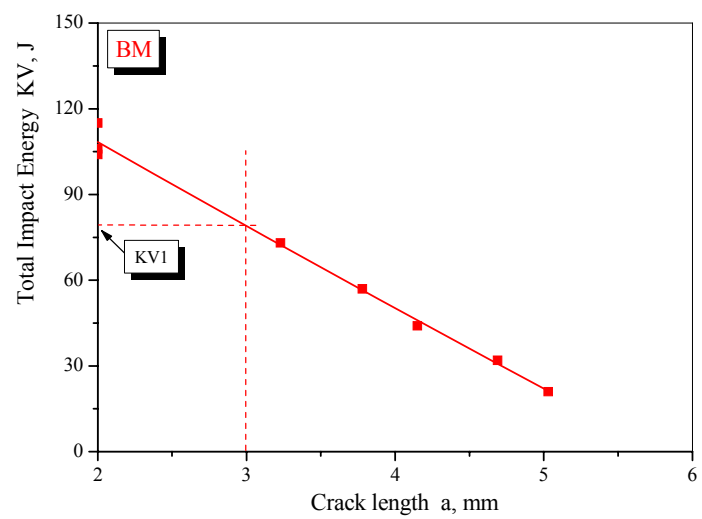

Figure 8. Diagram impact energy KV vs. crack length a for base metal specimens

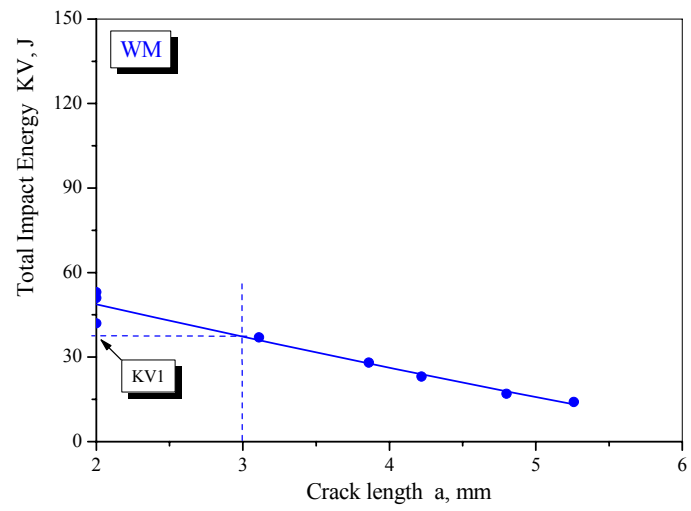

Figure 9. Diagram impact energy KV vs. crack length a for weld metal 


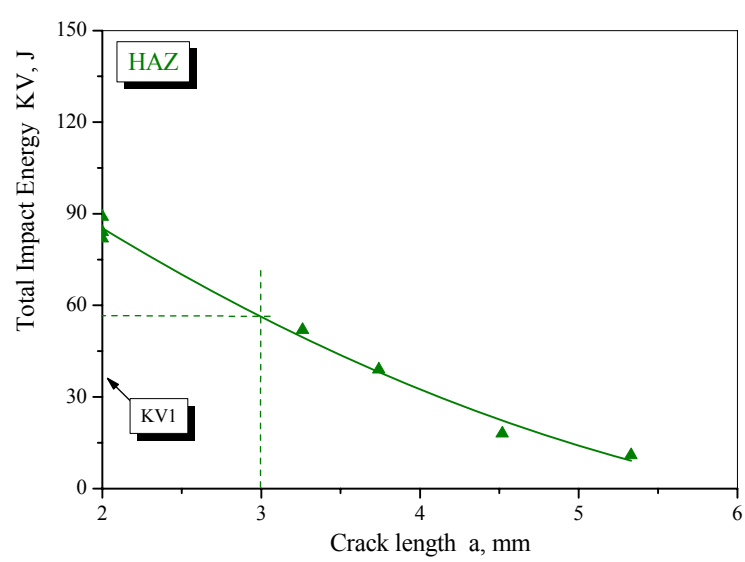

Figure 10. Diagram impact energy KV vs. crack length a for HAZ

It is now possible to determine crack sensitivity (CS), defined as the ratio of KV value for Charpy V notch specimen (average value from Table 5) and KV1 value, corresponding to $1 \mathrm{~mm}$ crack extension (total crack length $a=3 \mathrm{~mm}$ ) [9], taken from Figures 8 - 10:

$$
C S=\frac{K V}{K V 1}
$$

Calculated values of crack sensitivity are tabulated in Table 6 .

Table 6. Crack sensitivity factors for base metal, weld metal and heataffected-zone

\begin{tabular}{||c|c|c|c||}
\hline Specimen type & Notched specimen & Cracked specimen & $\begin{array}{c}\text { Crack sensitivity } \\
\text { CS }\end{array}$ \\
\hline \hline & $\mathrm{KV}$ & $\mathrm{KV} 1$ & $\mathrm{KV} / \mathrm{KV} 1$ \\
\hline Base metal & 107 & 79 & 1.36 \\
\hline Weld metal & 49 & 37 & 1.32 \\
\hline $\begin{array}{c}\text { Heat-affected- } \\
\text { zone }\end{array}$ & 85 & 57 & 1.49 \\
\hline
\end{tabular}

Performed experiments enable to consider separately and compare the behavior under impact loading of welded joint constituents (BM, WM and HAZ) specimens, containing notch and crack.

The results in Table 5 reveal that the impact toughness of $\mathrm{BM}$ is satisfactory, at high level for this type of steel. The results obtained in HAZ are still satisfactory, but they are low for WM, where the part for crack propagation is probably critical. It is to notice that in all considered cases crack initiation energy level is almost of the same value, and the difference is due to crack propagation energy. Obtained results agree in general with data from material specification. The differences in HAZ behavior can be attributed to different microstructure in HAZ, and the question is in which microstructure region is notch tip positioned. Crack propagation energy of WM is higher in specification than that given in Table 5 .

The diagrams obtained under impact loading with precracked specimens (Figures 5 - 7) for all three welded joint constituents present a brittle behaviour. This can be explained by a deep initial crack: in BM crack length was $a=5,03 \mathrm{~mm}$, in WM $a=5,26$ $\mathrm{mm}$ and in HAZ $a=4,52 \mathrm{~mm}$. In order to compare the behavior of different regions, crack sensitivity is determined, based on plots drawn in Figures $8-10$. For the crack length value of 1 $\mathrm{mm}$, calculated crack sensitivity factor is 1.36 for BM, 1,32 for WM and 1.49 for HAZ. These relations can be accepted as offering proper description of relation between individual welded joint constituents behavior [6].
Having in mind that weld metal in this welded joint is a constituent of minimum crack resistance properties, expressed in impact toughness of notched as well as of cracked specimens and in plane strain fracture toughness value, there is a space to consider how to improve welding technology parameters. This can be achieved by selection of other electrode or by adopting welding regime parameters, e.g. heat input.

\section{Fracture mechanics parameters}

Fracture mechanics parameters (stress intensity factor $\mathrm{K}$ and $J$-integral [16]) have been tested with the single edge (SE) three-point bend (B) specimens, fatigue-precracked in BM, $\mathrm{WM}$ and HAZ, and bent in support span, $\mathrm{S}$, equal to four times width, $4 \mathrm{~W}$, following the procedure for single specimen compliance technique, standardized in ASTM E1820 [10]. Testing has been performed at room temperature on electrical mechanical testing machine. Crack opening displacement has been monitored by a clip-gauge, with accuracy $\pm 0,001 \mathrm{~mm}$.

Two types of records are necessary for $J$ integral determination: load $\mathrm{F}$ vs. crack opening displacement (COD), $\delta$, and J-integral vs. $\Delta a$. Typical curves load $F-\delta$, and $J-\Delta \mathrm{a}$ curves obtained by $\mathrm{SE}(\mathrm{B})$ specimens in static loading are presented in Fig.11 for BM, Fig.12 for WM and Fig.13 for HAZ specimens.

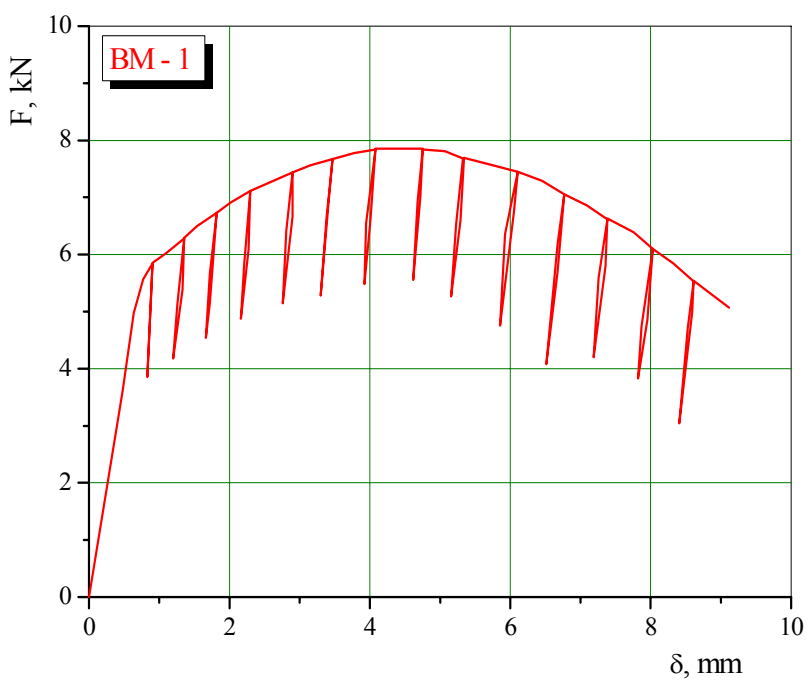

a)

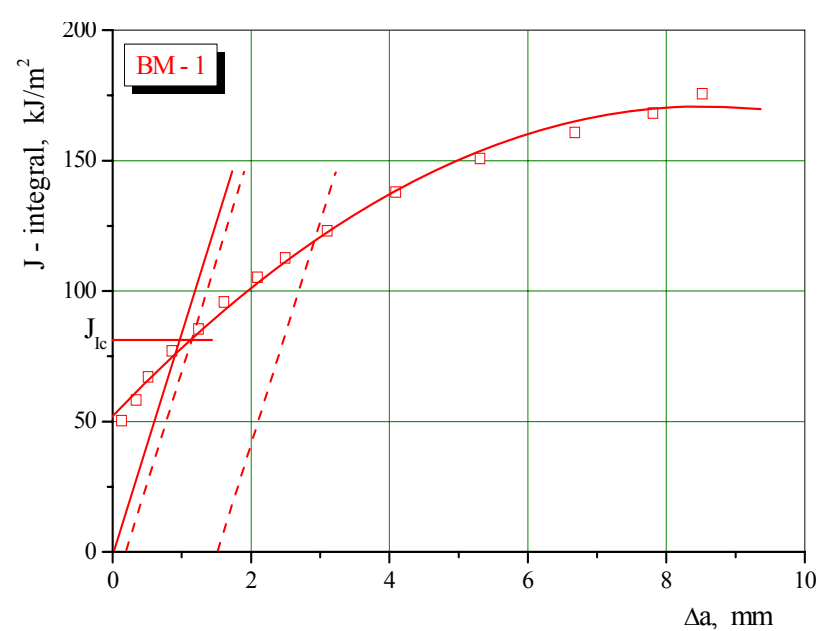

b)

Figure 11. Diagrams load $F-\delta$ (a), and $J-\Delta a$ (b) for BM-1 specimen 


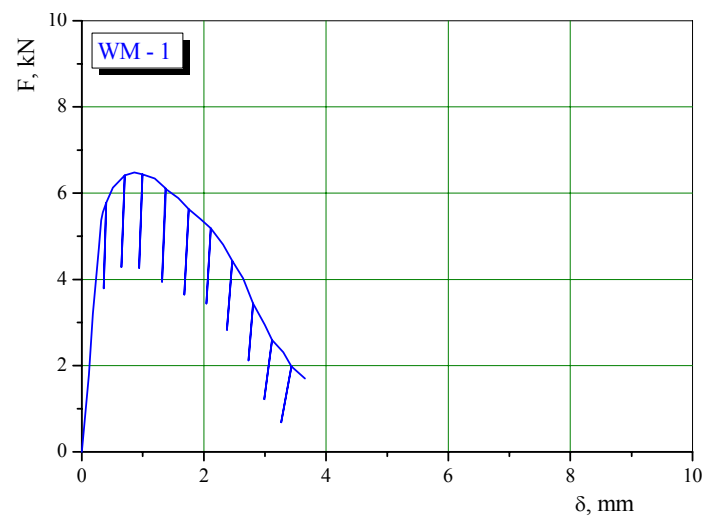

a)

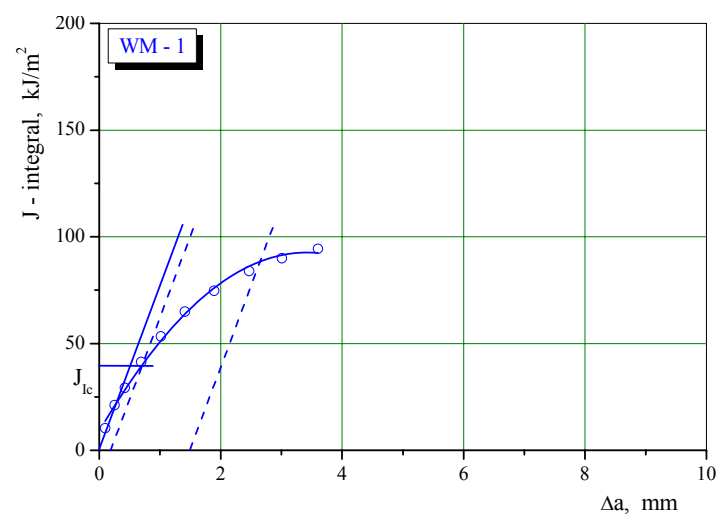

b)

Figure 12. Diagrams load $F-\delta($ a), and $J-\Delta a$ (b) for WM-1 specimen

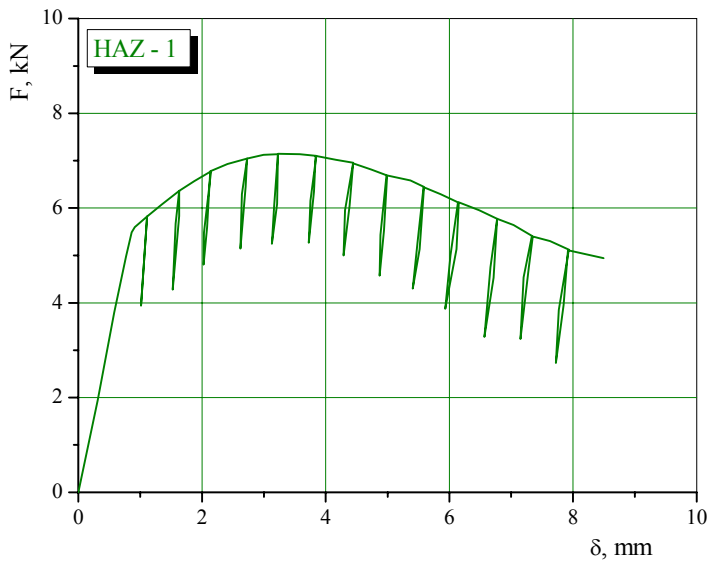

a)

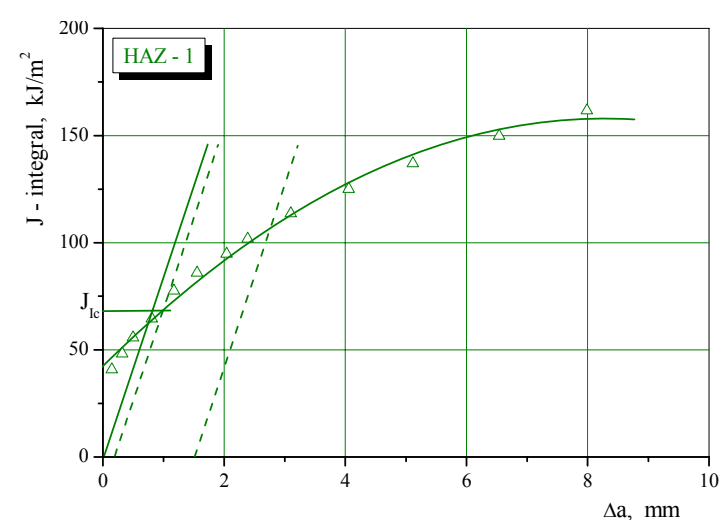

b)

Figure 13. Diagrams load $F-\delta($ a), and $J-\Delta a($ b) for HAZ-1 specimen

It is possible to use the critical $J$ integral value, $J_{I c}$, for calculation of critical stress intensity factor, $K_{I c}$, applying the relationship:

$$
K_{I c}=\sqrt{\frac{J_{I c} \cdot E}{1-v^{2}}}
$$

Obtained results for critical stress intensity factor, $K_{I c}$, are summarized in Table 7.

Table 7. The results of testing critical J-integral and plane-strain facture toughness $K_{I c}$

\begin{tabular}{|c|c|c|}
\hline \hline \multirow{2}{*}{ Specimen No. } & Critical J-integral & Plane-strain facture toughness \\
\cline { 2 - 3 } & $J_{I c}, \mathrm{~kJ} / \mathrm{m}^{2}$ & $K_{I c}, \mathrm{MPa} \sqrt{\mathrm{m}}$ \\
\hline \hline BM-1 & 81 & 136.7 \\
\hline BM-2 & 84 & 139.2 \\
\hline BM-3 & 87 & 141.7 \\
\hline WM-1 & 39 & 94.9 \\
\hline WM-2 & 36 & 91.1 \\
\hline WM-3 & 41 & 97.3 \\
\hline HAZ-1 & 68 & 125.3 \\
\hline HAZ-2 & 61 & 118.6 \\
\hline HAZ-3 & 64 & 121.5 \\
\hline
\end{tabular}

\section{Fatigue crack growth rate testing}

Fatigue crack will initiate and propagate from severe stress raisers under variable loading after determined cycle number if the stress-intensity factor range, $\Delta K_{t h}$, for fatigue threshold is achieved. The structure can be used before growing crack reaches critical value, based on performed structural integrity analysis. Substantial data for the decision about extended service of cracked component is crack growth rate and its dependence on acting load. Standard ASTM E647 [11] defines testing of pre-cracked specimen for fatigue crack growth rate measurement $\mathrm{da} / \mathrm{dN}$, and calculation of stress intensity factor range, $\Delta K$. Two basic requirements in standard ASTM E647 are crack growth rate above $10^{-8}$ $\mathrm{m} /$ cycle to avoid threshold $\Delta K_{t h}$ regime, and testing with constant amplitude loading.

Standard Charpy size specimens, pre-cracked in different welded joint regions, were tested under variable loading for determination of stress-intensity factor range at fatigue threshold, $\Delta K_{t h}$, and fatigue crack growth rate da/dN. Testing was performed in load control, by three-points bending on highfrequency resonant pulsator CRACKTRONIC, Fig.14. This FRACTOMAT device is based on electrical potential measurement, connected with corresponding instruments, Fig. 15. For monitoring of the crack growth, foil crack gauges RUMUL RMF A-5, $5 \mathrm{~mm}$ long, were cemented on the machined specimens, applying the same procedure as for classical strain gauges. During crack propagation, gauge foil breaks following the fatigue-crack tip. In that way, resistance of the gauge foil varies linearly with crack length variation [12].

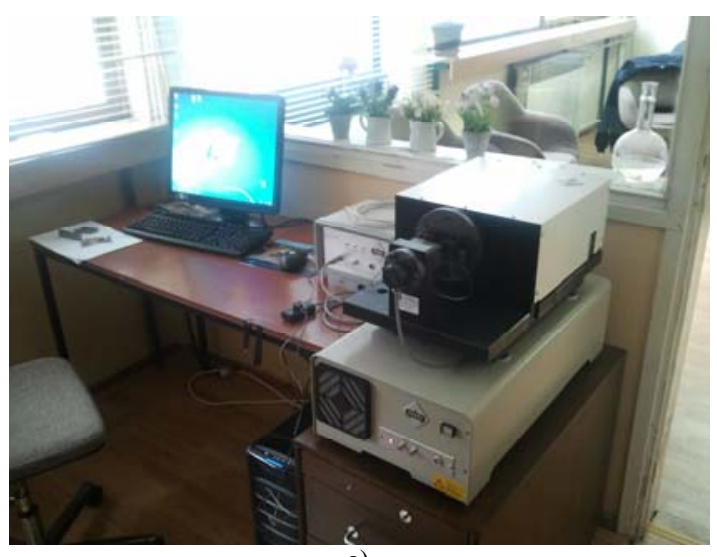

a) 


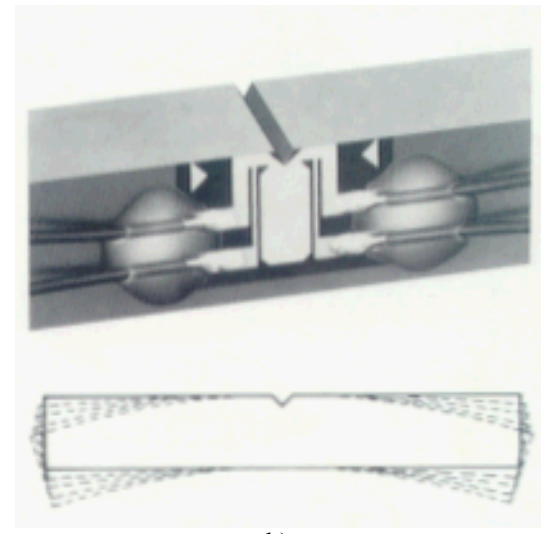

b)

Figure 14. High frequency bend fatigue testing system FRACTOMAT (a) with device CRACKTRONIC for crack length monitoring (b)

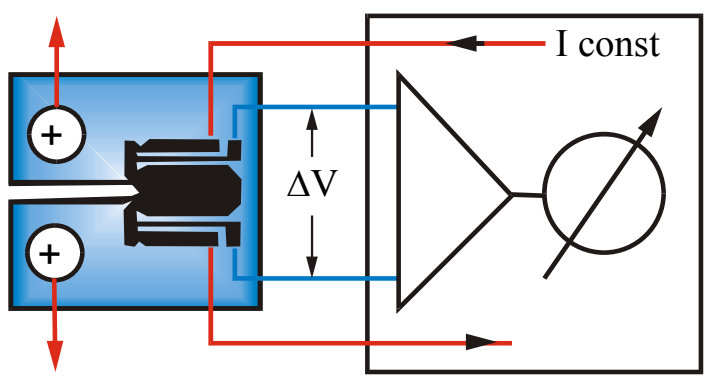

Figure 15. Schematic diagram of crack gauge foil function

Welded structures can contain small pre-existing cracks. They will propagate under repeated loads up to critical size, at which fracture occurs. In that case the entire life is spent in the propagation phase, and additional data of the crack growth rate behavior is necessary for overall fatigue life computation. Since the zone ahead the crack tip, exposed to cyclic plasticity, is small, necessary plane-strain conditions is developed even for small thickness and data obtained by thin specimens can be applied quite generally.

Fatigue crack growth rate testing is performed with notched and precracked $\mathrm{SE}(\mathrm{B})$ specimens (width $W=10 \mathrm{~mm}$, thickness $B=10 \mathrm{~mm}$, span $S=4 \mathrm{~W}$ ) of base metal, weld metal and heataffected-zone (HAZ), on the CRACKTRONIC dynamic testing device in FRACTOMAT system [12]. The system produced pure bending moment, composed of static and dynamic parts, of the ratio $R=0.1$. Number of cycles has been automatically registered for each $0.1 \mathrm{~mm}$ crack growth, determined by thin crack gauge, which enabled the design of relationship crack length a vs. number of cycles $N$. From these curves it is possible to derive data, necessary for the Paris law [13]:

$$
\frac{d a}{d N}=C(\Delta K)^{m}
$$

Here, $\mathrm{da} / \mathrm{dN}$ is growth in crack size a per unit cycle, $\mathrm{N}$ is cycle number, $C$ and $m$ are constants obtained from experiments, $\Delta K=K_{\max }-K_{\min }$ is stress intensity factor range in the loading cycle [13].

Obtained relationships da/dN vs. $\Delta K$ for base metal, weld metal and HAZ are given in Fig.16. Obtained parameters $C$ and $\mathrm{n}$ in the Paris law, together with fatigue threshold $\Delta K_{t h}$ values are tabulated in Table 8 .

When welded steel structures are exposed to variable loading of high level it is necessary to reduce stress concentration as much as possible. Performed experiments have shown that this can be achieved by complete machining of welded joints.

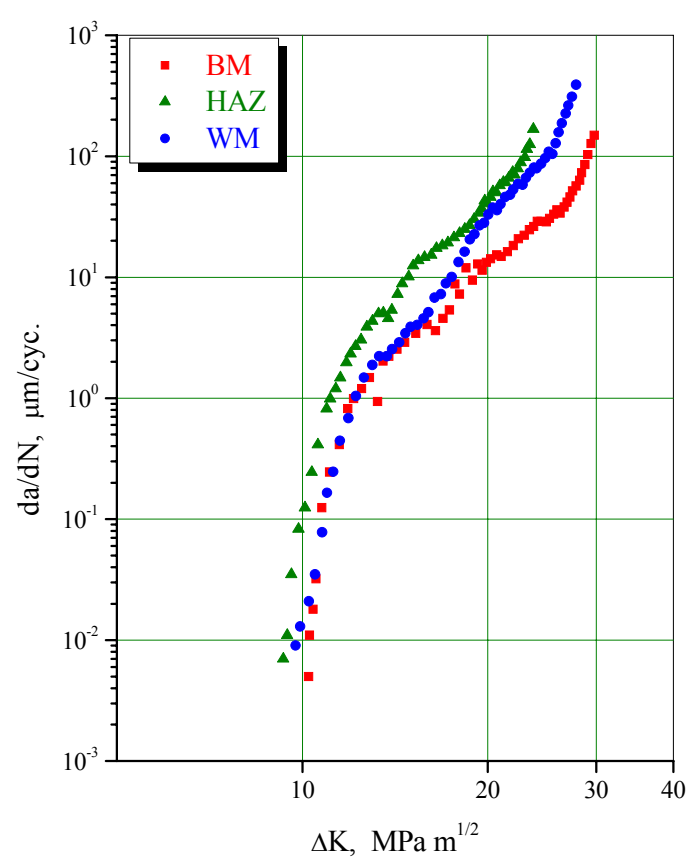

Figure 16. Diagram da/dN - $\Delta K$ for BM, HAZ and WM [5]

Table 8. Parameters $\mathrm{C}$ and $\mathrm{m}$ and fatigue threshold $\Delta K_{t h}$ value for BM, WM and HAZ

\begin{tabular}{|c|c|c|c|}
\hline Paris equation & $\mathrm{C}$ & $\mathrm{m}$ & Fatigue threshold. $\Delta K_{t h}, \mathrm{MPam}^{1 / 2}$ \\
\hline \multicolumn{4}{|c|}{ Basic Metal (BM) } \\
\hline I & $3.98 \cdot 10^{-14}$ & 4.139 & \multirow{2}{*}{10.22} \\
\hline II & $1.67 \cdot 10^{-13}$ & 3.765 & \\
\hline \multicolumn{4}{|c|}{ Weld Metal (WM) } \\
\hline I & $8.38 \cdot 10^{-15}$ & 4.798 & \multirow{3}{*}{9,11} \\
\hline II & $3.30 \cdot 10^{-19}$ & 8.462 & \\
\hline III & $7.93 \cdot 10^{-15}$ & 5.078 & \\
\hline \multicolumn{4}{|c|}{ Heat Affected Zone (HAZ) } \\
\hline I & $\begin{array}{c}1.90 \cdot 1 \\
0^{-20} \\
\end{array}$ & 10.259 & \multirow{6}{*}{8,51} \\
\hline II & $\begin{array}{c}4.63 \cdot 1 \\
0^{-12} \\
\end{array}$ & 2.667 & \\
\hline III & $\begin{array}{c}2.90 \cdot 1 \\
0^{-16} \\
\end{array}$ & 6.403 & \\
\hline IV & $\begin{array}{c}7.87 \cdot 1 \\
0^{-13} \\
\end{array}$ & 3.560 & \\
\hline $\mathrm{V}$ & $\begin{array}{c}1.48 \cdot 1 \\
0^{-16} \\
\end{array}$ & 6.505 & \\
\hline VI & $\begin{array}{c}1.74 \cdot 1 \\
0^{-14}\end{array}$ & 4.929 & \\
\hline
\end{tabular}

While the "smooth bar" ( $\mathrm{S}-\mathrm{N})$ approach to fatigue is undoubtedly useful, most components do not have smooth, highly polished surfaces. In the smooth bar or $\mathrm{S}-\mathrm{N}$ methodology, results are usually given in terms of the total life to failure with no indication of the life fraction spent in the initiation and propagation phases. Anyhow, welded structures usually contain small pre-existing cracks. They will propagate under repeated loads up to critical size, at which fracture occurs. In such cases, the entire life is spent in the propagation phase. For that, additional knowledge of the crack growth rate behavior is imperative if the overall fatigue life is to be computed. The stress-intensity factor range $\Delta \mathrm{K}$ characterizes the cyclic stresses and strains ahead of the crack tip and uniquely characterize the crack growth rate through a relationship such as equation 15 . Since the zone ahead of the crack which experiences cyclic plasticity is small, plane-strain conditions can develop even for small thicknesses [14].

This is an important conclusion since it means that data can be obtained from thin specimens and applied quite generally. 
In regime I of the Paris relation the crack growth rate is low since the threshold for crack propagation is approached. In regime II the so-called Paris law (Eq.3) is obeyed, while in regime III the crack growth rate increases above that predicted by the Paris equation since the fracture toughness of the material is approached and there is local tensile overload fracture. Material behavior in the regime I can be considered in a similar way as endurance limit, because in both cases there is no crack growth [5].

The life of components containing pre-existing flaws can be in principle computed using fracture mechanics concepts. For complex load/crack geometries and stress patterns, the equations for $\Delta K$ are complex. In addition, the da/dN vs. $\Delta K$ relationships may be quite complicated (or perhaps not even available in functional form). Such conditions do not lead to easily evaluated integrals for the fatigue life.

It is interesting that the difference in fatigue threshold value, the value of stress intensity factor range, $\Delta K_{t h}$, at which existing crack will not grow is not significant: it is $10.22 \mathrm{MPa}$ $\mathrm{m}^{1 / 2}$ for base metal, 9.11 MPa $\mathrm{m}^{1 / 2}$ for weld metal and 8.51 $\mathrm{MPa} \mathrm{m}^{1 / 2}$ for heat-affected-zone [5].

\section{Conclusion}

The application of high strength steel and its welded joint in structures, exposed to high loads can be accepted if the properties satisfy strong requirements. The benefits which can be obtained by increased strength must be additionally confirmed by sufficient toughness and crack resistance when applied loading can cause crack initiation or crack propagation, e.g. impact loading or variable loading. For that reason, data about $\mathrm{V}$ notch impact toughness and crack behavior in impact and in stable crack growth condition, as well as in fatigue, are required before final decision for the selection of high strength steel for manufacturing responsible welded structures.

Applied techniques in this experiment enabled the evaluation of parameters, important for the application of high strength steel welded joint. It is to underline that crack-like defects can be expected in welded joint due to the nature of welding procedure, and data about crack resistance of the welded joint constituents are necessary for a successful application of high strength steel.

It has been shown that the crack resistance of weld metal and heat-affected-zone is reduced compared to parent metal, and this has to be taken into account when welded structure is designed with high strength steel.

Performed experimental analyses of welded joint samples in low cycle fatigue regime have shown significant reduction in fatigue properties of high strength steel welded joint. Fatigue cracks developed from unavoidable defects in welded joint, positioned in weld metal or in HAZ. Since fatigue limit of as-welded sample is very low, up to the level that application of high strength steel is not reasonable, the measures to improve fatigue limit are necessary. Some improvement is achieved by grinding of overfill, but better result is obtained by machining of overfill.

General conclusion is that high strength steels can be applied in pressure vessel design after taken measures for improvement of crack resistance of their welded joints.

\section{References}

[1] PELLINI,W.S.: Guidelines for fracture-safe and fatigue-reliable design of steel structures, The Welding Institute, 1963, Abington, Cambridge.

[2] BURZIĆ,M., PROKIĆ-CVETKOVIĆ,R., POPOVIĆ,O., BURZIĆ,Z.: Effect of Structural Heterogeneity on the Fracture Mechanics Parameters of Welded Joints of A.387, Scientific Technical Review, ISSN 1820-0206, 2014, Vol.64, No.4, pp.39-44.

[3] SEDMAK,A.: Application of Fracture Mechanics in Structural Integrity, Monograph, Faculty of Mechanical Engineering, Belgrade, 2003.

[4] BURZIĆ,Z.: Savremene metode provere mehaničko-tehnoloških osobina zavarenih spojeva-Deo 2, Zavarivanje i zavarene konstrukcije, 2002, Vol.47, No.3, pp.151-158.

[5] BURZIĆ,Z., BURZIĆ,M., GRABULOV,V., PERKOVIĆ,S, MANJGO,M.: Fatigue of high strength steel weldment in pressure vessels application, 9 . International Scientific-Professional Conference, Engineering Technologies in Manufacturing of Welded Constructions and Products, 2017, Slavonski Brod, CROATIA, pp.347-353

[6] GRABULOV,V., BURZIĆ,Z., BURZIĆ,M., PERKOVIĆ,S, MANJGO,M.: Testing of Impact Properties of Welded Joints by Notched and Precracked Specimens, 9. International ScientificProfessional Conference, Engineering Technologies in Manufacturing of Welded Constructions and Products, 2017, Slavonski Brod, CROATIA, pp.354-361.

[7] EN ISO 9016, Destructive tests on welds in metallic materials - Impact tests - Test specimen location, notch orientation and examination, 2013.

[8] ASTM STP 563, Instrumented Impact Testing, ASTM, 1974, Philadelphia, USA.

[9] DOBI,Đ.: The effect of structural state of steel on crack sensitivity (in Croation), Ph Tesis, Faculty of Mechanical Engineering and Ship Building, 1988, Zagreb, YUGOSLAVIA..

[10] ASTM E1820, Standard Test Method for Measurement of Fracture Toughness, Annual Book of ASTM Standards, 2016, Vol. 03.01.

[11] ASTM E647, Standard Test Method for Constant-Load-Amplitude Fatigue Crack Growth Rates Above $10^{-8} \mathrm{~m} / \mathrm{cycle}$, Annual Book of ASTM Standards, 2007, Vol. 03. 01.

[12] DOBI,Đ.: Žilavosna proba i mehanika loma, Četvrta letnja škola mehanike loma, Perspektive razvoja mehanike loma, 23-27 juni 1986, Dubrovnik, YUGOSLAVIA, str.367-374

[13] PARIS,P.C., AND ERDOGAN,F.: A Critical Analysis of Crack Propagation Laws, Trans. ASME, Journal Basic Eng., 1963, Vol.85, No.4, p.528.

[14] ZRILIĆ,M., GRABULOV,V. BURZIĆ,Z., ARSIĆ,M., SEDMAK,S.: Static and Impact Crack Properties of a High-Strength Steel Welded Joint, International Journal of Pressure Vessels and piping, 2007, Vol. 84, No.3, pp.139-150. 


\title{
Uticaj prsline na karakteristike zavarenog spoja pri različitim vrstama opterećenja
}

\begin{abstract}
Primena čelika visoke čvrstoće kod projektovanja zavarenih konstrukcija zahteva podatke o svojstvima istih pri različitim uslovima opterećenja. Zahvaljujući visokom naponu tečenja debljina zida može se smanjiti u poređenju sa opštim konstrukcijskim čelicima, a shodno tome, dimenzije zavarenog spoja, potrošnja dodatnog materijala za zavarivanje i vreme za izradu zavarenih spojeva će biti minimizirani. Ovo je od značaja za opremu pod pritiskom, ali i za druge industrijske grane (kranove, bagere). Kompletna karakterizacija zavarenog spoja mora uključiti podatke za osnovni metal, ali takođe su neophodne osobine metala šava i zone uticaja toplote (ZUT), bar da bi ih uporedili sa svojstvima osnovnog metala. Ovo je od posebnog značaja zbog heterogenosti strukture u ZUT-u.
\end{abstract}

Ključne reči: mikrolegirani čelik, zavareni spoj, kvalitet zavarenog spoja, prskotina, zamorna prskotina, rast prskotine, ispitivanje udarom, zamor materijala, mehanika loma.

\section{Influence de la fissure sur les caractéristiques du joint soudé pour les différents types de charge}

\begin{abstract}
L'application de l'acier de haute dureté dans la conception des constructions soudées exige les données sur leurs propriétés pour les différentes conditions de charge. Grâce à la haute tension de production l'épaisseur de mur peut se réduire en comparaison des aciers communs de construction et par conséquent les dimensions du joint soudé, la consommation du matériel supplémentaire de soudure et le temps pour la fabrication des joints soudés seront minimisés. Cela est important pour l'équipement sous pression et aussi pour les autres branches industrielles ( grues, excavateurs). La caractérisation complète du joint soudé doit inclure les données pour le métal de base. Les propriétés du métal soudé et de la zone de l'influence de chaleur (ZUT) sont nécessaires aussi pour être comparées avec les propriétés du métal de base. C'est de l'importance particulière à cause de l'hétérogénéité de la structure dans le ZUT.
\end{abstract}

Mots clés: acier micro allié, joint soudé, qualité du joint soudé, fissure, fissure de fatigue, croissance de fissure, essai de choc, fatigue de matériel, mécanique de fissure.

\section{Влияние трещины на чрезвычайные сварочные совместные характеристики в различных типах нагрузок}

\begin{abstract}
Применение высокопрочной стали в проектировании сварных конструкций требует данных об их свойствах в разных условиях нагружения. Из-за высокого напряжения потока толщина стенки может быть уменьшена по сравнению с общими конструкционными сталями, и, соответственно, размеры сварного соединения, потребление дополнительных сварочных материалов и время изготовления сварных соединений будут сведены к минимуму. Это важно для оборудования под давлением, но и для других отраслей промышленности (краны, экскаваторы). Полная характеристика сварного шва должна включать данные для основного металла, а также необходимы и свойства металлических швов и зоны теплообменника (ЗОT), по крайней мере, для сравнения со свойствами основного металла. Это имеет особое значение из-за неоднородности структуры в 3ОT.
\end{abstract}

Ключевые слова: микролегированная сталь, сварные соединения, качество сварных соединений, трещина, усталостная трещина, рост трещин, ударные испытания, усталость материала, механика разрушения. 